\title{
Advocating for Net-Zero Energy Sustainable Houses through the International Solar Decathlon Competition
}

\author{
Timothy J McCarthy, Brendan J Banfield, Yeganeh Baghi, Luca Faidutti, Clayton McDowell \\ University of Wollongong \\ NSW Australia
}

\begin{abstract}
The US Department of Energy has been running the Solar Decathlon since 2000. This contest challenges teams of university students to design, build and operate a solar powered net-zero energy house. The contests are held in the US and at locations around the world. Transporting the house to the contest location is a major challenge for the teams. The University of Wollongong became the first Australian team to enter the Solar Decathlon when it's house was constructed at Datong, China for the SD China 2013 competition. Team UOW won that competition against 18 other universities from around the world. The university will be in the final of the Solar Decathlon Middle East 2018 to be held in Dubai in October/November of that year. The new house, named Desert Rose, is a net-zero energy, dementia friendly eco house designed for the harsh Gulf climate.

This paper will summarise the history of the 16 Solar Decathlon contests to date. The impact of the competition on the 235 international teams will be examined to demonstrate how the Solar Decathlon is a vehicle for educating engineers, architects and universities about sustainable and net-zero energy buildings. Case studies, including Team UOW's winning entry to SD China 2013 will examine the value of such a large educational initiative from multiple perspectives. The paper will conclude with an update on the Solar Decathlon Middle East and an examination of the sustainability and dementia friendly features of the Desert Rose House.
\end{abstract}

\section{Introduction}

The Solar Decathlon competition, often described as the 'Energy Olympics', is the largest sustainable building research and innovation competition in the world, with teams designing, building and operating net-zero energy, solar powered houses. Solar Decathlons are organized by the US Department of Energy in collaboration with local hosts such as the Dubai Electricity and Water Authority (DEWA) for the Middle East contest. The Solar Decathlon challenges collegiate teams from all over the world to design and build a solar-powered house that is cost-effective and attractive. During the final phase of the competition teams transport their houses to the competition site, assemble and present them to the judges and the general public.

The aim of the Solar Decathlon movement is to demonstrate how, well designed homes with all modern conveniences can become net-zero energy homes through the application of solar energy and demand management. The competition is a vehicle to educate engineers and architects of the future who operate in a multidisciplinary team to create the most sustainable buildings possible. The contests also have the aim to raise public awareness of the importance of renewable energy, sustainability and energy efficiency.

The aims were further elaborated by Vega- Sánchez and Rodriguez Ubiñas [1] when the Solar Decathlon was held in Europe:

"Promoting the innovation and knowledge generation to improve energy efficiency and sustainable conditions of cities and buildings, and the integration of renewable energies, transferring all that knowledge to the industry and professionals, with the aim of generating a critical mass of technicians integrating this knowledge in their daily activities.

Taking advantage of the social and media interest aroused by the Competition, to make people aware of the importance of a responsible use of energy, developing a more sustainable world all together."

\section{History of SD}

Solar Decathlon was first held in 2002 in the United States of America and over the past two decades it has spread to nearly all continents. Table-1 shows the road map for the Solar Decathlon contest based on their location and year. Since 2005 there has been a US based solar decathlon every two years, with the Washington Mall being the location for most. The 2013 and 2015 Decathlons were held in Orange County, California. The 2017 contest was held in Denver, Colorado. 
International contests have been held in Madrid, Spain (2010 and 2012), Versailles, France (2014), Datong, China (2013), Cali, Columbia (2015, 2018).

Table 1: Solar Decathlon Finals 2002-2019.

\begin{tabular}{|l|l|l|}
\hline Finals Year & Location & Winning team \\
\hline 2002 & National Mall, Washington DC, USA & University of Colorado \\
\hline 2005 & National Mall, Washington DC, USA & University of Colorado \\
\hline 2007 & National Mall, Washington DC, USA & Technische Universität Darmstadt \\
\hline 2009 & National Mall, Washington DC, USA & Technische Universität Darmstadt \\
\hline 2010 & Madrid, Spain & Virginia Tech, USA \\
\hline 2011 & Orange County, California, USA & University of Maryland \\
\hline 2012 & Madrid, Spain & $\begin{array}{l}\text { École Nationale Supérieure d'Architecture de } \\
\text { Grenoble (France) }\end{array}$ \\
\hline 2013 & Orange County, California, USA & Vienna University of Technology \\
\hline 2013 & Datong, Shanxi Province, China & University of Wollongong, Australia \\
\hline 2014 & Versailles, France & Universitá Degli Studi di Roma TRE (Italy) \\
\hline 2015 & Orange County, California, USA & Stevens Institute of Technology \\
\hline 2015 & Cali, Columbia & Universidad ORT Uruguay \\
\hline 2017 & Denver, Colorado, USA & EPFL, Geneva, Fribourg, Switzerland \\
\hline 2018 & Dezhou, Shandong Province, China & \\
\hline 2018 & Dubai, UAE & \\
\hline 2019 & Szentendre, Hungary & \\
\hline 2019 & Morocco & \\
\hline 2019 & Cali, Columbia & \\
\hline
\end{tabular}

In 2018, there will be the first competition in Middle East, to be held at the Mohammad Bin Rasheed Al Maktoum Solar Park in Dubai. 2018 also sees the second SD China competition to be held in Dezhou, Shandong province. The first Solar Decathlon on the continent of Africa is planned for Morocco in 2019 as is the next Solar Decathlon Europe to be held in Szentendre near Budapest [2].

As a decathlon, there are 10 sub-contests in the overall event. These contests change slightly from one competition to the next and comprise a mix of measured or objective performances and judged or subjective contests.

Table 2: Decathlon sub-contests 2002 and 2018.

\begin{tabular}{|l|l|}
\hline 2002 Solar Decathlon, Washington DC & 2018 Solar Decathlon Middle East \\
\hline Design and livability & Architecture \\
\hline Design presentation and simulation & Engineering and construction \\
\hline Graphics and communication & Communication \\
\hline The comfort zone & Comfort conditions \\
\hline Refrigeration & House functioning \\
\hline Hot water & Energy efficiency \\
\hline Energy balance & Energy management \\
\hline Lighting & Sustainability \\
\hline Home business & Innovation \\
\hline Getting around (Electric vehicle charging and use) & Sustainable transportation (EV charging and usage) \\
\hline
\end{tabular}


A number of the original 2002 contests have been merged into the 2018 House functioning contest. As the availability of low cost PV eventuated, the Energy Balance contest has moved from a simple net-zero balance to Energy management with constraints on the total output of the PV array.

\subsection{Competition Schedule}

Solar decathlons typically take place over a one month period. This begins with an initial construction period. This was 6 days in 2002 and has stretched to 12 days for 2018 Middle East contest. This has expanded as the geographical spread of the entries has grown. In the 2002 contest, all but one (University of Puerto Rico) were based on the mainland USA. As seen in Table-1, the number of international teams has increased. These international teams typically use containerized shipping, adding to the assembly time, while the more local teams can transport larger components by road.

\section{Impact of Solar Decathlon Competitions 2002-2018}

The two major impacts of the Solar Decathlon are technology advancement and training of the next generation which will be discussed in this section.

\subsection{Technology Advancement}

Since the start of Solar Decathlon competitions, challenging students to think about the related existing problems and finding innovative solutions, have been inseparable goals [3]. Delivering innovative ideas within Solar Decathlon houses and implementing them and as a result showcasing them within the competition period to public can result in technology advancement.

Dr Richard King, the founder and Director of the 2002 Solar Decathlon stated, "Competitions accelerate research and development and increase public awareness - the two key ingredients necessary to accelerate progress. We not only need technical advancements, but we need people to accept and use them. The two work hand in hand to push designs forward and assimilate them into society. In the end, everyone benefits." in [4].

Initially, the focus was on achieving the required energy generation through solar PV panels and solar hot water. In the 2005 Solar Decathlon, a spell of unseasonably cloudy weather meant that the available solar radiation was less than $30 \%$ of that which had occurred in the 2002 event. This meant that most teams struggled to meet the net-zero energy target. Many teams sacrificed energy balance to maintain thermal comfort and keep the lights on, while other teams made different compromises [5]. In the 2013 Solar Decathlon China competition, almost all teams achieved net zero energy balance. Team UOW's 2013 entry, The Illawarra Flame, had a 9.4KW Photovoltaic (PV) system comprising two types of PV cells. A thin-film CIGS array operated on both the north and south sides of the roof and works well in low and diffuse light. A poly-crystalline PV array, over a substantial section of the roof, generates power at high electrical efficiency [6] . As PV technology has matured, later contests such as SDME2018 have moved to controlling energy demand while maintaining thermal comfort. For example, the 2018 Middle East contest limits the inverted PV output to $8 \mathrm{~kW}$ [7].

Figure 1 lists the non PV innovations. These include Heating Ventilation and Air-conditioning (HVAC); Architectural design; Adaptability of the building, furniture and appliances to different life styles and climates; Building material; Integration of different features into the body of the building as well as different spaces of it. Recent Solar Decathlons include designing fully smart houses.

\subsection{Training the Next Generation}

As the aim of Solar Decathlon is to provide communities with information and education about opportunities and advantages of clean energy products for designing and building sustainable and high-energy efficiency solar powered house. The competition also aims to showcase the accessibility and comfort of houses that combine energy efficient construction and appliances with renewable energy systems available today [3]. These aims of Solar Decathlon competition, on the one hand and the worldwide expansion of the competition over the passage of time (shown in Figure 2) on the other hand, makes this competition have a significant impact on informing the general public, providing involved students with better and new job opportunities.

One of the important aspects of largescale competitions such as the Solar Decathlon is that they engage students in real and complex learning activities that are relevant to their degrees. According to Barth et al. [8] it is very difficult to develop key competencies for sustainable development in a university curriculum because it requires the opportunity for both 
formal and informal learning in an interdisciplinary environment where students can develop self-responsibility. TorresAntonini studied 24 students who took part in a Solar Decathlon event and concluded that the scale and difficulty of the project are important factors that contribute to sustainability competence and development of leadership skills [9]. Further evidence of how the Solar Decathlon competition has provided an invaluable vehicle to engage the public, industry and academia in promoting excellence in renewable energy and sustainable buildings teaching and research is outlined by Kos and de Souza [10]. Thus, the Solar Decathlon provides an excellent vehicle for linking research activities in solar power, sustainable housing, energy modelling, modular construction etc. with learning activities and practical outcomes. Figure 2 highlights the geographical of the Solar Decathlons up to 2018. The countries in red are ones that have entered at least one previous decathlon. The blue countries are those entering for the first time in 2018. By extending the host sites to the Middle East in 2018 and Morocco in 2019, the proportion of the globe actively engaged in the Solar Decathlon will be greatly expanded.

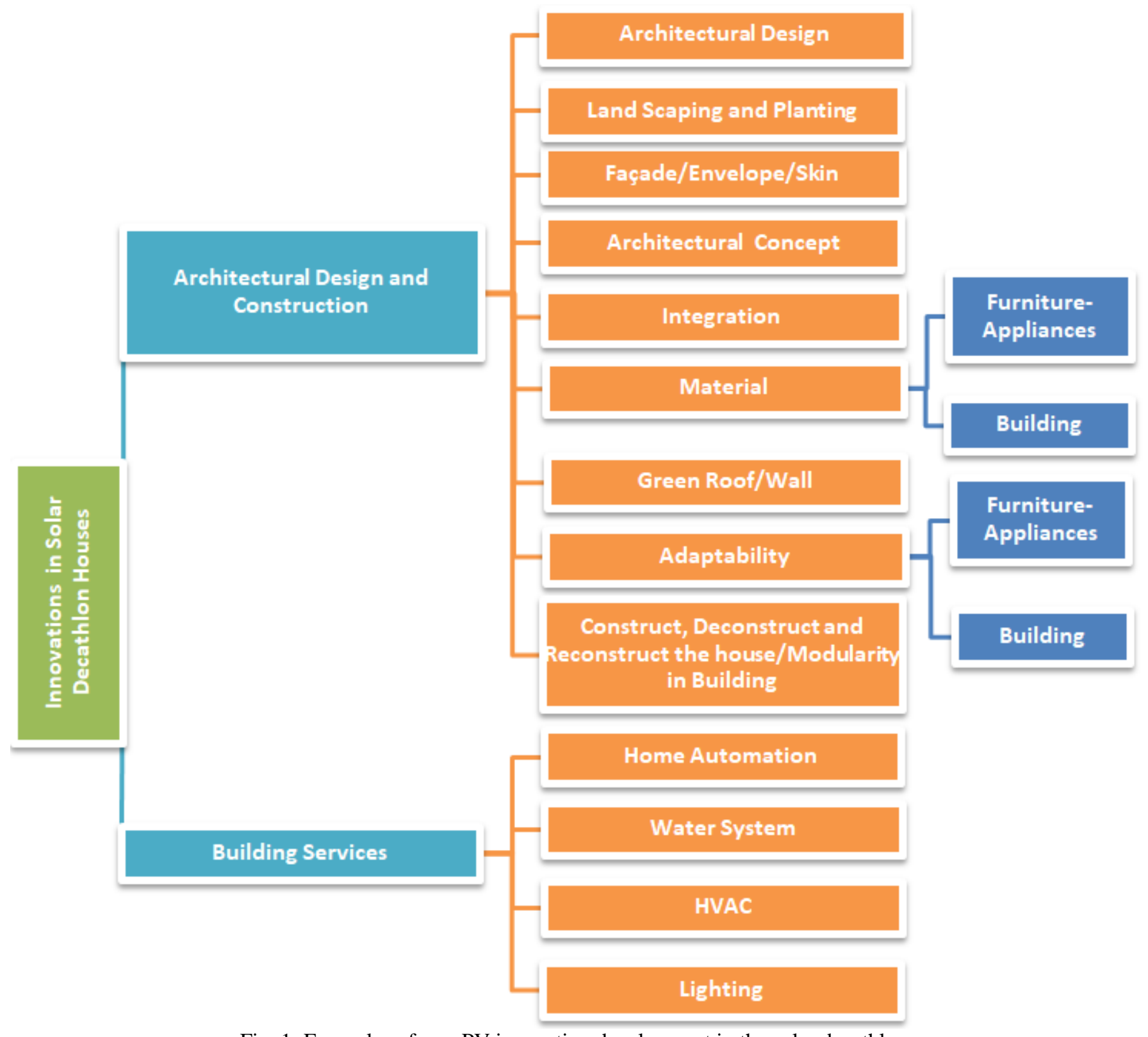

Fig. 1: Examples of non-PV innovation development in the solar decathlon. 


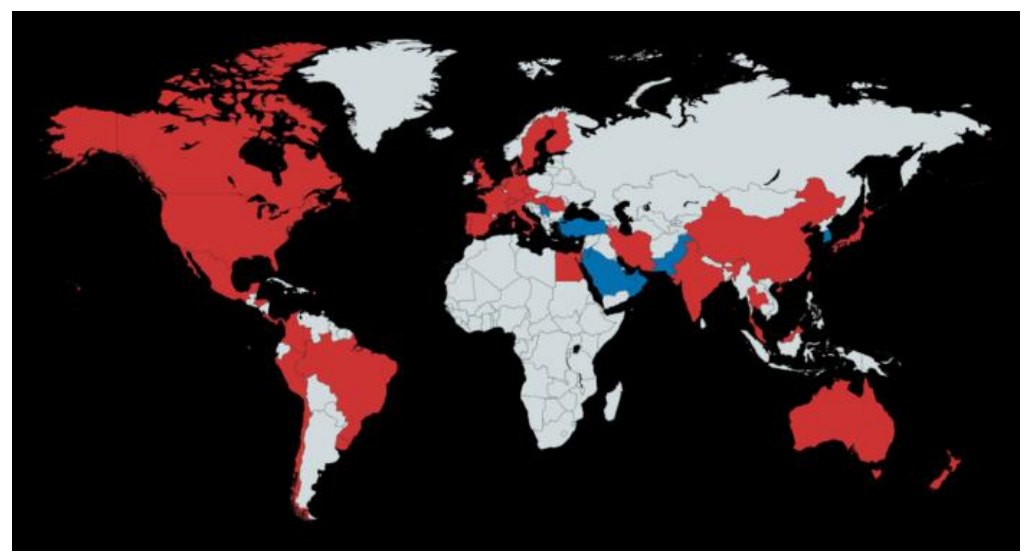

Fig. 2: The geographical spread of entrants to Solar Decathlons.

\section{Case Study - Solar Decathlon China, the Illawarra Flame House (IFH) 4.1. UOW's Entry into the Solar Decathlon}

By 2011, the author, McCarthy and colleague Paul Cooper had been considering entering an Australian team in the Solar Decathlon for some time. We were inspired by the entry of Victoria University, New Zealand's entry, First Light, in the 2011 US Solar Decathlon [11]. The Faculty held a student competition to send two representatives to Washington DC where the 2011 competition was to be held at the West Potomac Park in the Washington Mall. Our student representatives witnessed First Light achieving 3rd place overall in the September early autumn sun.

Having gained many insights from the New Zealand team, it was decided to put together a Wollongong entry for the 2013 US contest. All successful entrants were to receive seed funding of US\$100,000 to get the ball rolling. The timing was tight, with entries required by November 2011. At that time, the Solar Decathlon China 2013 was announced and so UOW put an entry for that contest too. By January, it was announced that Team UOW was successful in becoming the first Australian university team to gain entry to the US and also the China contests. Given the geographic relative proximity to China, the already strong academic ties with that country and the opportunities for greater cultural education for our students, the university opted to concentrate on the Solar Decathlon China 2013 contest.

Much of the detail about the planning, organization and fundraising challenges is covered in [12]. The importance of recruiting a strong student leadership team and providing adequate postgraduate scholarships had been learnt from our New Zealand colleagues. It still took until mid 2012 to assemble the core leadership team, leaving less than 1 year to complete construction and send the house by sea to China.

\subsection{Solar Retrofit - Illawarra Flame House}

Team UOW's approach was to apply a solar and energy upgrade to a typical Australian "fibro house". Such houses were constructed in great numbers to meet the housing needs of immigrants during the 1950s through to the 1970s. The Aussie fibro is famous locally for being very hot in summer and cold in winter. The cladding is asbestos sheeting and the overall construction quality results in a drafty house with very poor energy performance.

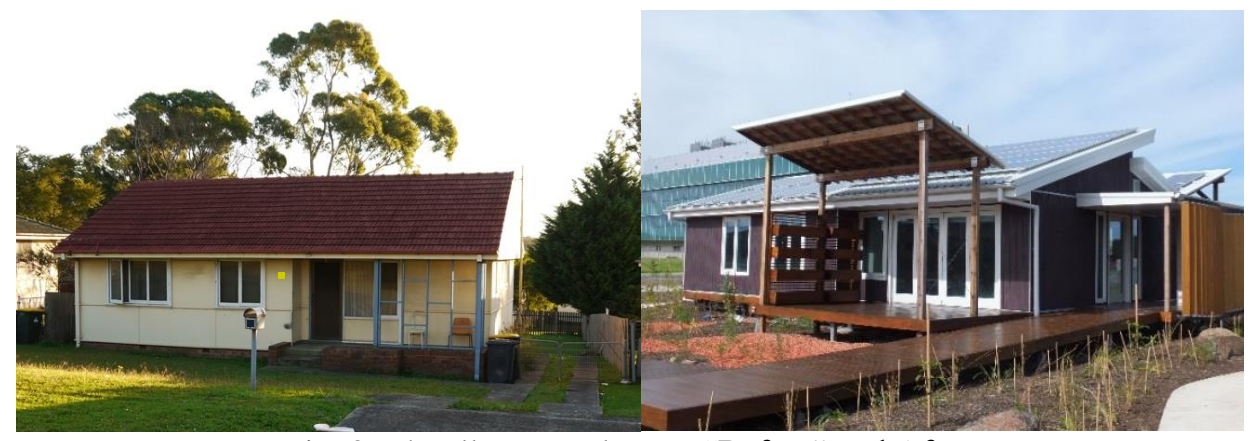

Fig. 3: The Illawarra Flame - "Before" and After. 
Although, styled as a retrofit, the Illawarra flame house had to be constructed from scratch to meet the needs of transporting from Wollongong to Datong, $400 \mathrm{~km}$ west of Beijing. The floor plan was kept close to the typical three bedroom house shown in Figure 3 and Figure 4. The modifications to the floor plan were designed to show how best to transform a small and congested three bedroomed house into a more spacious two bedroomed cottage, suitable for a retired couple. The third bedroom was removed to create an open plan living and kitchen area. Add-on bathroom and laundry pods extended the floor space slightly as did a clip-on bay window to the two remaining bedrooms. Part of the roof was extended to facilitate the addition of north facing clerestory windows and to provide more space for solar PV panels. The ceiling in the new lounge and dining area was raised to form a cathedral style ceiling giving access to the light from the clerestory windows.

\subsection{Construction Method}

Amongst the toughest challenges in the solar decathlon is the requirement to cost effectively transport the house to the competition site and then build it in the short time available. For Solar Decathlon China, teams had only 10 days to complete construction and commission their houses. At the end of the contest, they had 5 days to disassemble the house and re-pack it into containers for shipping home.

These requirements meant that the Illawarra Flame House (IFH) needed to be pre-fabricated and modularized for rapid assembly. The scheme chosen would facilitate the IFH being built a total of 4 times and disassembled 3 times. Team UOW joined forces with the local vocational training college, TAFE NSW which trains plumbers, carpenters, electrician and builders and the first construction took place at the TAFE campus.
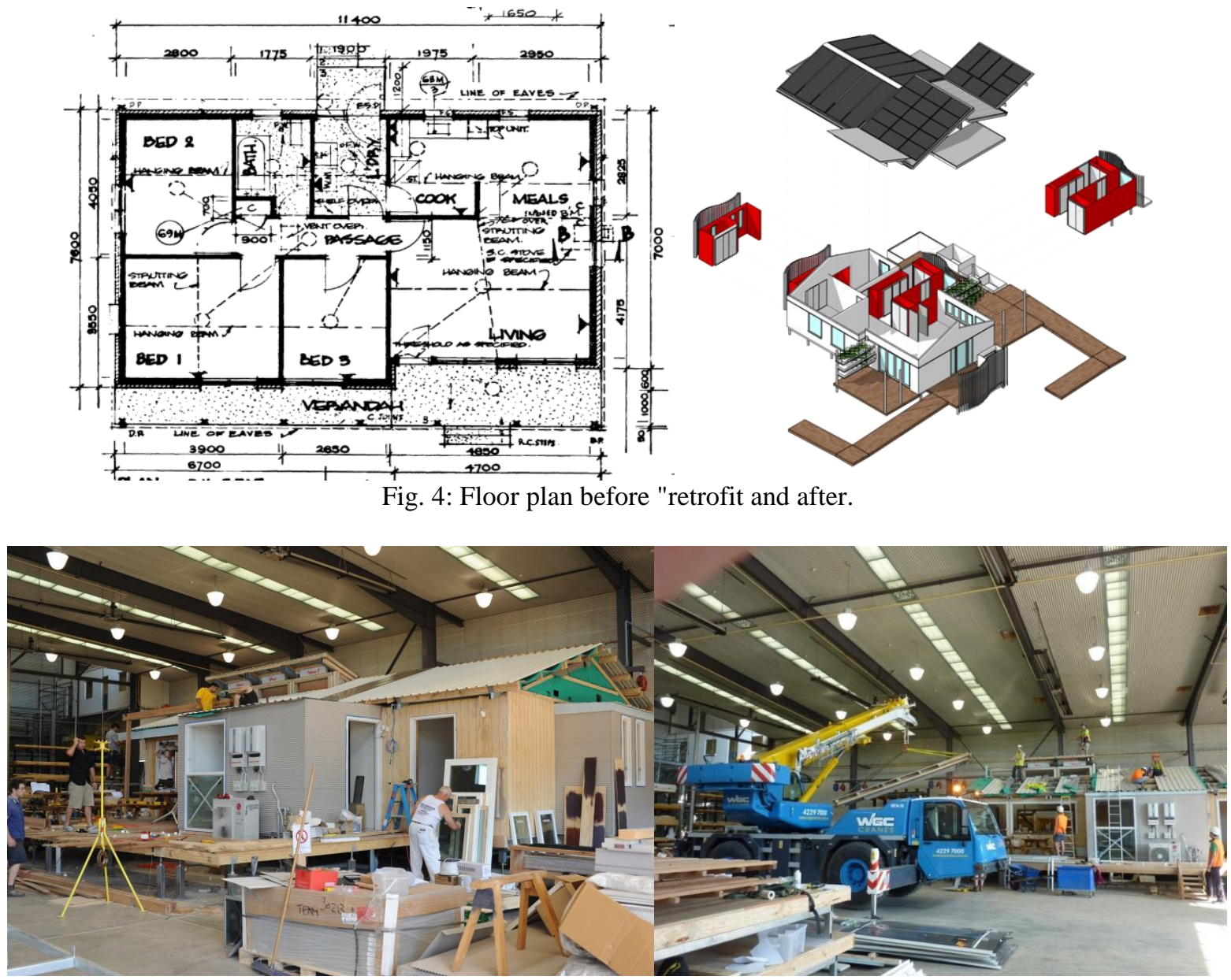

Fig. 5: Construction and disassembly at TAFE NSW campus. 
The modularization consisted of assembling the 6 floor cassettes as fully finished units comprising SHS peripheral members, LVL timber joists, cypress flooring and the layers of insulation (Earthwool between joists and $75 \mathrm{~mm}$ Knauf insulation board at the base. The top part of the piers were welded to the peripheral frame. The fully finished cladded walls were split into 10 panels, while the bathroom and laundry pod comprised two volumetric units. This pod was the largest single unit.

After building the IFH at TAFE, the team instantly disassembled it, packed it in containers and transported it across Wollongong to begin a practice re-assembly and to complete the commissioning of the HVAC and PV in the open air. Reassembling in the elements presented new challenges as the team experience a wild autumn storm. Nevertheless, the construction was made weather tight within 7 days and the house was opened to the public within 2 weeks.

Once final commissioning of the HVAC and PV systems was completed and after a short testing schedule, the house was once again dis-assembled in 5 days, packed in seven $40 \mathrm{ft}$ shipping containers and sent on its way to China.

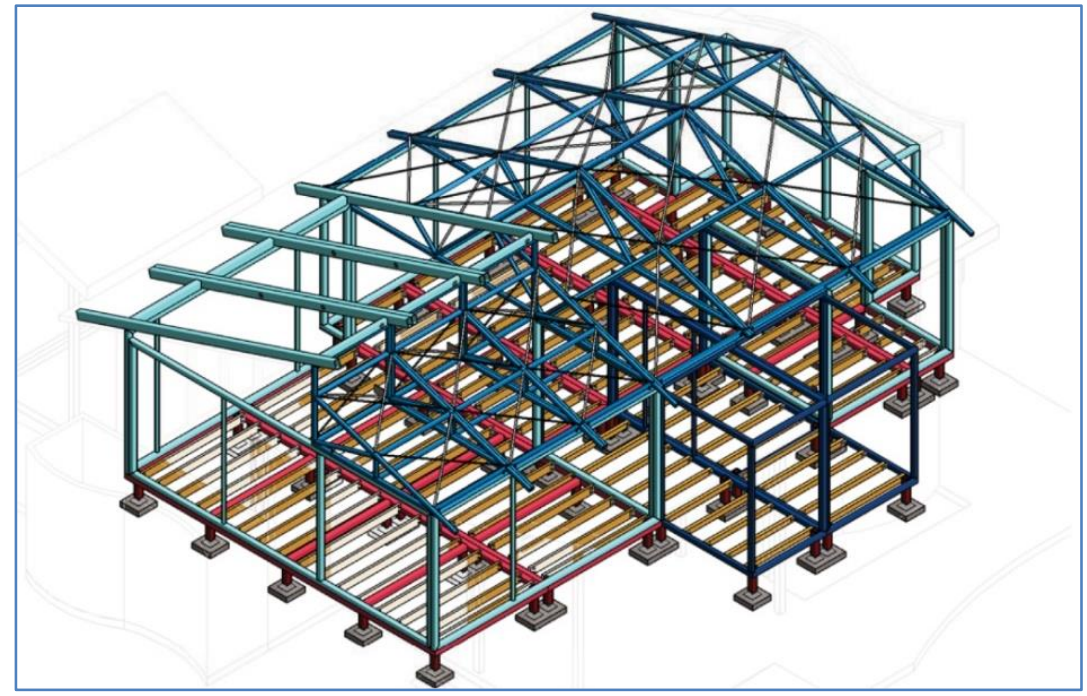

Fig. 6: IFH Structure - Colour coded modular segments.

\subsection{Solar Application}

The Illawarra Flame has two forms of Photo Voltaic (PV) panels giving a combined maximum output of 9.4KW. A thin-film CIGS (copper indium gallium diselenide) array operates on both the north and south sides of the roof and works well in low and diffuse light. A poly-crystalline PV array, over a substantial section of the roof, generates power at high electrical efficiency. Twin $5 \mathrm{~kW}$ max inverters are included in the system. The thin film CIGS panels are affixed to metal sheets which in turn are mounted on the Trimdeck roofing sheet. This creates air ducts beneath the panel. Air is drawn from the eaves to the ridge, cooling the panel as the air heats. The hot air is fed to the phase change material thermal store described below. Cooling the panels on hot days improves the PV efficiency.

\subsection{HVAC and Thermal Comfort}

The HVAC system was required to maintain thermal comfort in the house during the measured contests. The room temperature was required to be between $22 \mathrm{C}-25 \mathrm{C}$ and humidity below $65 \%$. The HVAC is an air-based photovoltaicthermal (PVT) collector and a phase change material (PCM) thermal storage unit. Air is channeled under the thin film PV panels and collected at the ridge of the roof, before being fed to the PCM heat exchanger. The hot air causes the PCM to melt, extracting energy from the air by latent heat. The PCM stores the heat in winter. The system is integrated with a reverse cycle heat pump, in a ducted system. The system operates differently during winter and summer using daytime solar radiation and night-time sky radiative cooling, respectively. The PVT collector heats or cools fresh air from ambient and thereby provides heating or cooling either directly to the indoor space, or to the PCM storage unit. The heat stored in the PCM can be used later to condition the space or precondition the air entering the air handling unit. Analytical models 
for the PVT collector and PCM unit were developed in order to be easily implemented into a practical building management system (BMS) [13].

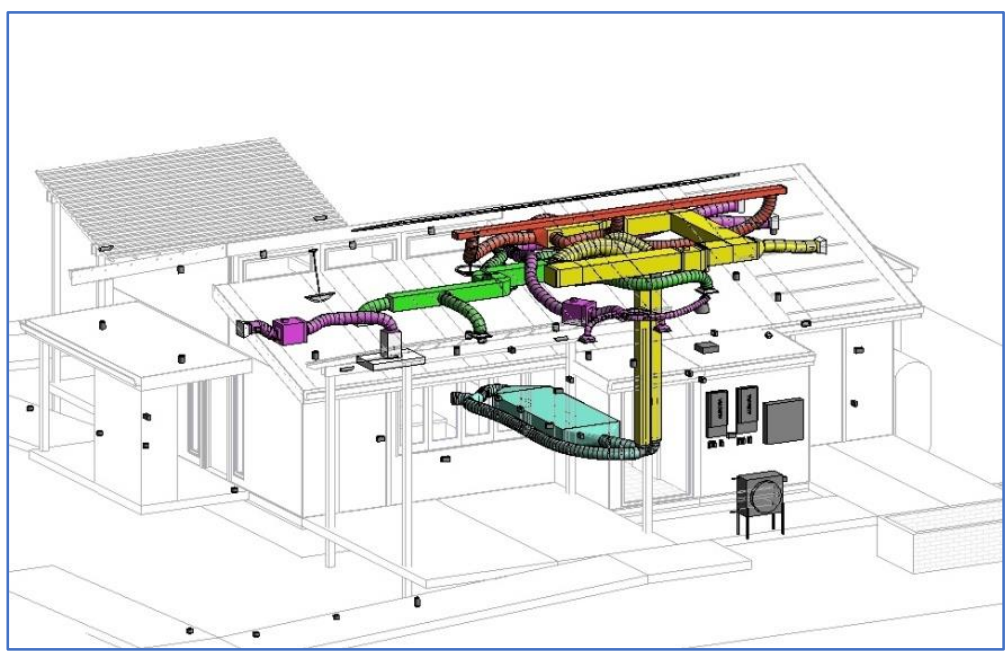

Fig. 7: HVAC showing AC ducting and phase change material thermal store (under the house).

\subsection{The China Contest}

A total of nineteen teams successfully delivered their houses to Datong, China for the 2013 contest which began in July. The site was very congested with 19 cranes and multiple truck movements during the construction phase which lasted 10 days. Figure 8 shows the multitude of cranes and Team UOW lifting one of the roof modules into place.
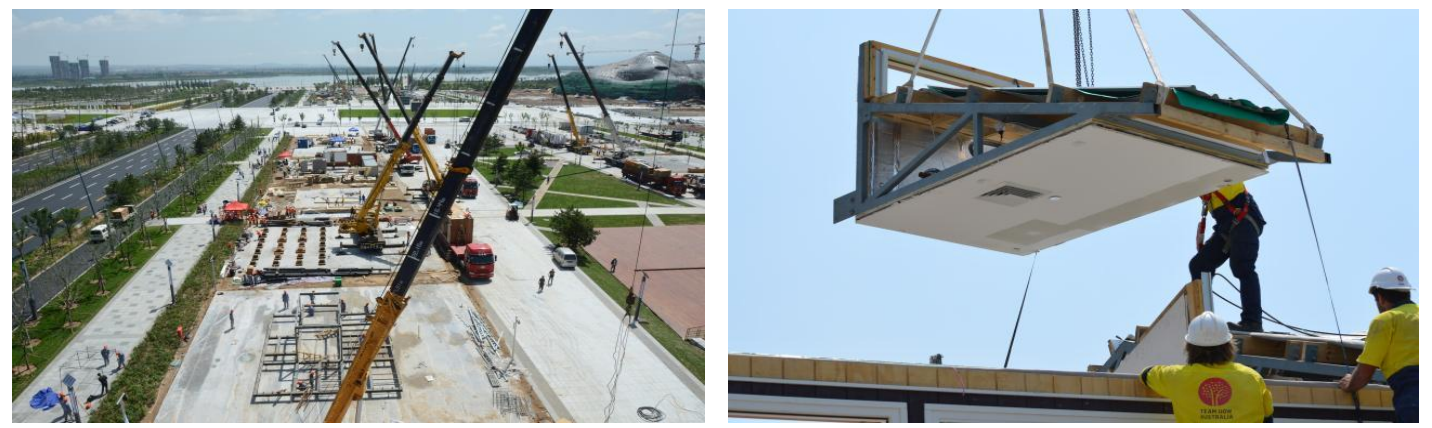

Fig. 8: Constructing the IFH in Datong China.

The practice assembly in Wollongong paid off as Team UOW was the first to complete their house in Datong and was the only team that did not work any night shifts during construction.

Eighteen of the teams completed construction in the allotted time. One team ran into difficulties because of the novelty of their Styrofoam construction and missed out on the measured contests.

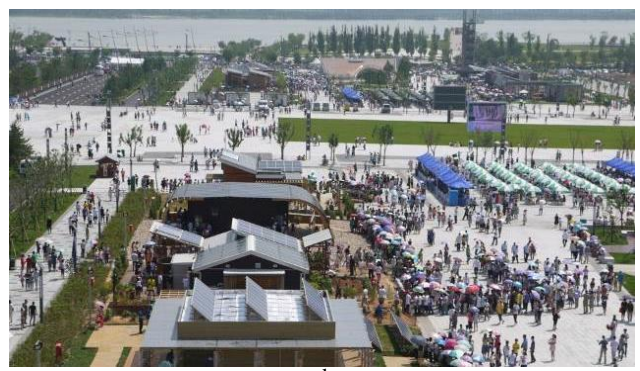

Fig. 9: IFH ( $2^{\text {nd }}$ from bottom $)$. 


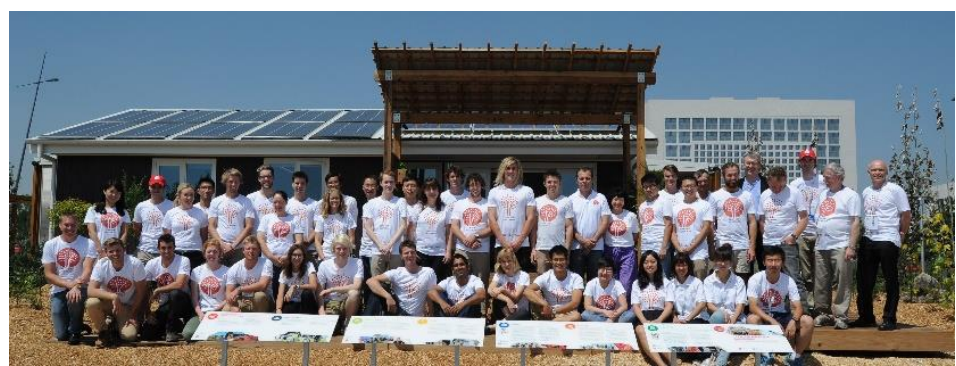

Fig. 10: Team UOW on day one of the measured contests.

The contest proved very popular with the Datong locals and visitors from across Shanxi province. Approximately 35,000 people toured through the IFH and it was estimated that about 300,000 visitors came to the contest over the 2 weeks of exhibition and competition.

Of the ten contests, Team UOW came outright first in Architecture, Engineering, Solar Application, joint first in Energy Balance and Hot Water, second in Communications, Market Appeal and topped the overall leaderboard with a world record total Solar Decathlon score of 957.6 points out of 1000.

The Illawarra Flame House returned to Wollongong where it has been re-built, its fourth construction following three dis-assemblies Figure 3 shows its current location where it serves as a living laboratory for optimizing the predictive building management system [14] and for ethnographic studies of occupants living in a sustainable dwelling.

\section{Case Study - Solar Decathlon Middle East - Desert Rose}

The Dubai Electricity and Water Authority (DEWA) and the US Department of Energy signed an agreement in June 2015 and launched the Solar Decathlon Middle East 2018 contest, inviting applications in early 2016 [15]. DEWA is the main sponsor and organizer. 44 applications were received by June 2016 and 21 teams were announced as successful candidates in October 2016.
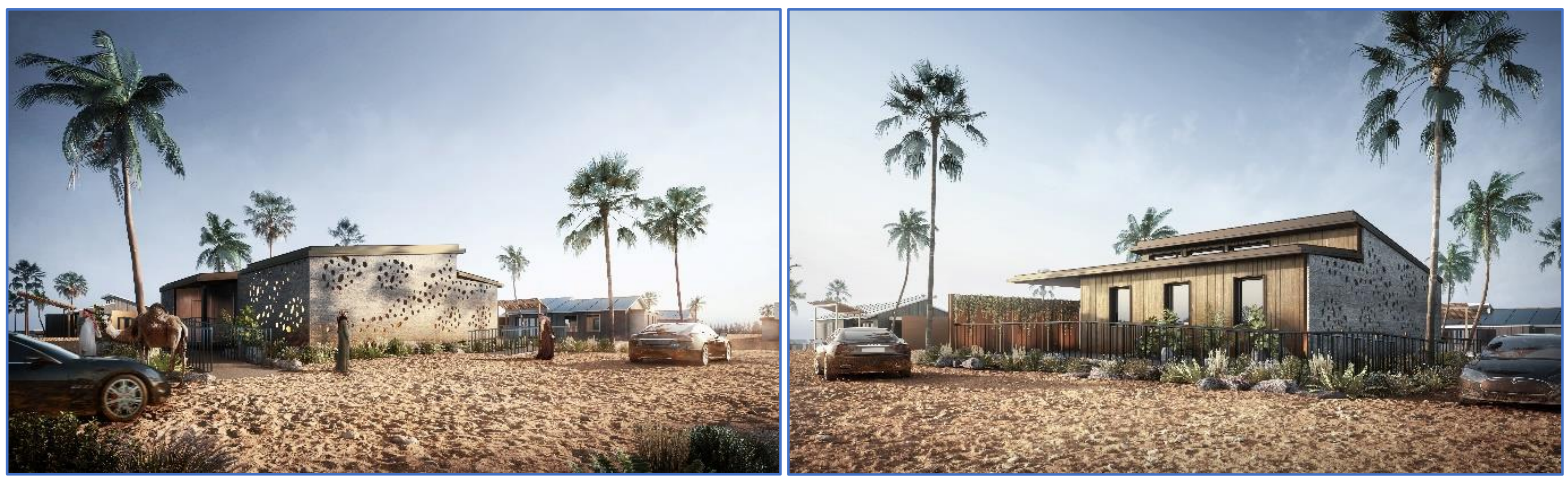

Fig. 11: Desert Rose House front and rear renders.

Team UOW Australia-Dubai, a collaboration between the University of Wollongong, TAFE NSW and the University of Wollongong in Dubai created an entry called Desert Rose. Unlike the IFH, this house is designed from scratch and aims to demonstrate how a house can cater for the needs of people living with dementia. This is in addition to the contest requirement for the house to be a super-sustainable, net-zero energy smart house. The harsh climate of Dubai, the cultural sensitivities of the Middle East and our desire to demonstrate dementia enabling architecture and technology make Desert Rose an interesting challenge for our students.

\subsection{Designing a Dementia Enabling House}

The word dementia categorises a broad number of disorders and brain diseases that affect thinking and often cause gradual decrease in the capacity to remember [16]. It is a condition that is currently affecting over 425,000 people in Australia, with the number increasing by an estimated of 250 each day. It is estimated that 318 people per day will be 
joining the population with dementia by 2025 , and more than 650 people by 2056 [17]. The inappropriate design of hospitals and aged-care facilities can pose severe risks to the person with a diagnosis of dementia and it often leads to disruptive behaviour difficult to manage by staff [16].

The Desert Rose is now leading the aged-care building industry, showcasing a house specifically built for people living with dementia and other aged-related diseases. The Desert Rose has been designed to assist elderly people to maintain their quality of life and continue living in their own home for as long as possible.

With reference to Fleming and Bennett's work [16], a number of key design principles were applied in the design of the Desert Rose with the explicit intention of developing a healthy and supportive environment for people with dementia. The layout of the house is specifically designed to help the occupants to navigate their home, allowing them to have clear visual access to the main areas of the house, independently of their location. Lighting and other visual cues are further employed to assist the residents to care for themselves, guiding them through their essential daily tasks. The house is also designed to be an independent living unit (ILU) within an Aged Care Village, and beautifully fit within the broader community, providing a variety of spaces for the occupants to be alone or with others.

Team UOW refined the design, obtaining the most appropriate footprint through a variety of training and courses, including Dementia Training Australia. A large number of health professionals were also consulted, and health-care workers, aged-care providers, Dementia Australia and other organisations were approached seeking feedback on design decisions and arrangements. As a result of these interactions, Desert Rose has now become an architecturally inspiring and affordable home, able to adapt to a person's needs as they continue to age and support them.

Line of sight as shown in Figure 12 play an important part in making the architecture work for a person living with dementia. Being able to see the toilet bowl increases the likelihood of it being used by someone in the advanced stages of Alzheimer's. For the Middle Eastern context, the house enables males and other family members to be separated while still having full access to amenities.

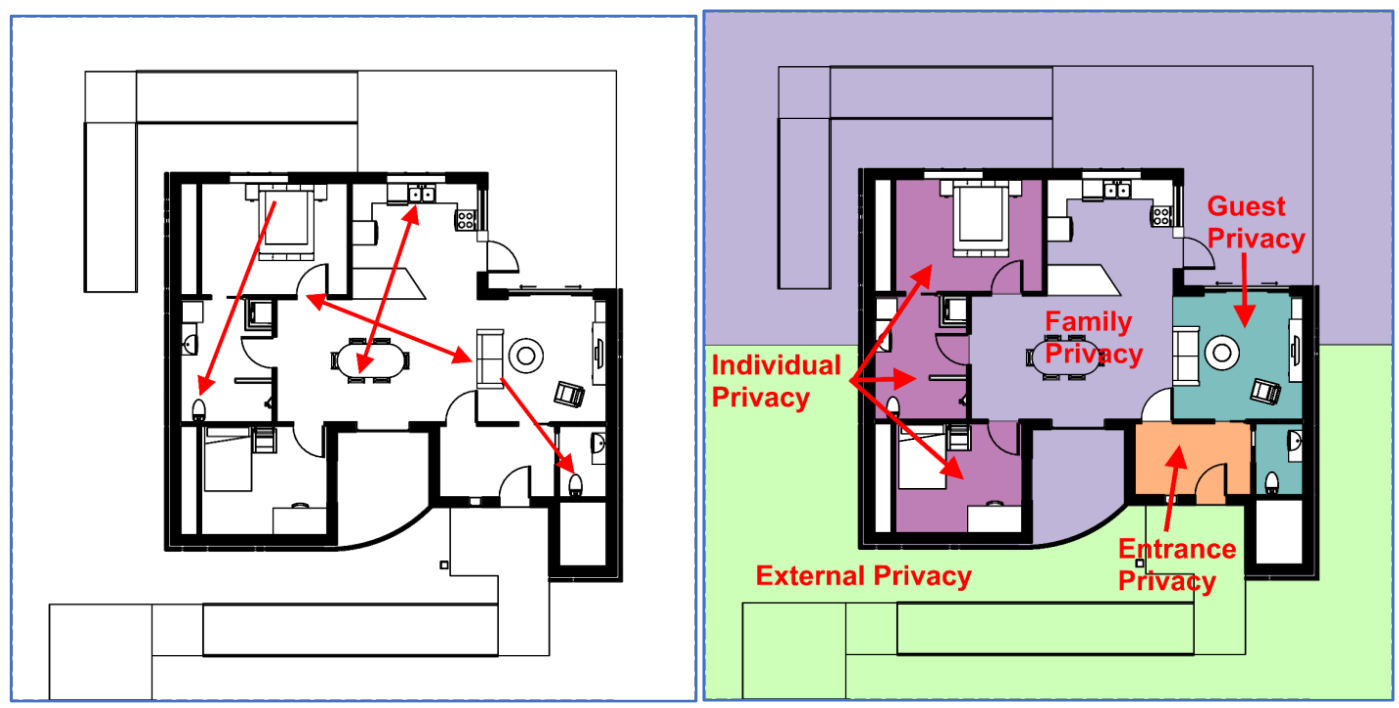

Fig. 12: Floor plan of Desert Rose House showing lines of sight and privacy zones.

\subsection{Light Gauge Steel Solution - Panelisation}

Like the Illawarra Flame House, the Desert Rose House (DRH) needs to be assembled and disassembled several times, and has to be erected on competition site in Dubai within a 12 day time limit. Transportation of the house components to site also plays a major role in the overall project planning, in view of the significant distance dividing Australia and the Middle East.

The DRH combines off-site fabrication methods with the aim of minimising the on-site work required for the erection of the structure, limiting transportation costs. Incorporating a panelised system to modular construction, the Desert Rose allows the optimisation of the two and three-dimensional components relating to spacial arrangements in the shipping containers, and fabrication costs. 


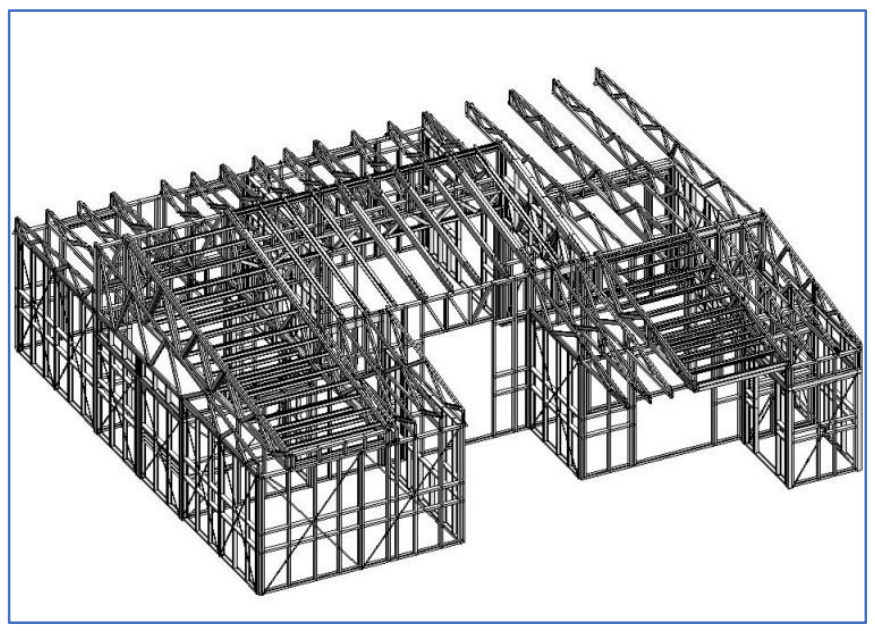

Fig. 13: Desert Rose House light gauge steel structure

While IFH used hot rolled perimeter steel frames with timber in-fill, DRH has adopted light gauge steel structure throughout for walls and roof trusses. The floor is a cold formed steel system also with heavier elements. As shown in the literature [18], light gauge steel (LGS) hybrid construction methods represent a cost-effective solution for low and mid-rise residential buildings, providing durability, adequate vertical and lateral loading counteraction, and sufficient rigidity during transportation and lifting. The DRH is adapting LGS as an effective engineering solution to the complexity of the Solar Decathlon competition. Pre-fabricated modules accompany house panels, and all components are reduced to the largest possible size to fit within the shipping containers. Each section can therefore be pre-fabricated, flat-packed for shipping and then assembled in Dubai.

Intelligent BIM computing technologies also support Team UOW's construction decisions, allowing for the generation of precise panel and module configurations, and accurate Bill of Materials (BOMs) and schedules well before construction. The software packages adopted during the design phase provided Team UOW a testing platform to verify the effectiveness and feasibility of the entire house design, and better facilitate following construction efforts.

\subsection{BIPV Solar Application}

The price of solar photovoltaics (PV) in recent years has been decreasing drastically. As of 2016 in Australia, the price of a residential solar PV system has dropped on average by 25-30\% since 2012 [19]. This has subsequently led to significant interest in the development of building integrated photovoltaics (BIPV) in both the research and industrial sectors.

The current low cost of this PV technology has meant that it can now replace standard construction materials in building elements such as roofs, walls, facades and even windows. Although the initial capital investment of BIPV may be higher than that of steel or glass, the ability to use the free solar energy locally means that the internal rate of return for BIPV can be significantly higher than that of standard construction materials. Along with the economic benefits, BIPV is often much more aesthetically pleasing than standard monocrystalline or polycrystalline solar panels which must be attached to roofs with large metal mounting racks. Finally, replacing construction materials with BIPV can also be viewed as more sustainable by reducing the total amount of materials required to construct a solar powered building.

The Desert Rose house will make use of BIPV that will entirely replace the regular materials required for the sloped section of the roof. Put simply, instead of the solar panels being attached to the roof, the solar panels become the roof. While the rated capacity of the BIPV roof will be $11.4 \mathrm{kWp}$, the inverted power is limited to $8 \mathrm{kWp}$. The panels will be in sub-optimal orientation for the November Dubai sun during the contest but are better oriented for the summer when greater power is needed. Along with producing electricity, the BIPV will also produce domestic hot water via pipes underneath the solar panels. The extreme Dubai temperatures will lead to significant heat being stored in the solar panels, by piping water underneath the roof, the panels essentially act as a heat exchanger, producing hot water that can then be used domestically throughout the house. Additionally, solar panels begin experiencing drops in efficiency when operating above 
their nominal operating cell temperature. The act of piping water underneath the PV will increase the overall system efficiency by decreasing the cell temperature in each panel, thus producing more energy over the life of the assets.

As the Desert Rose will be producing electricity and hot water with its BIPV, it can be thought of as a building integrated photovoltaic-thermal or BIPV-T system.

\subsection{HVAC in a Challenging Environment}

Designing an energy efficient HVAC system for a net-zero energy house in Dubai is a significant challenge. Due the extreme heat and humidity in Dubai, HVAC systems are often large and consume significant amounts of energy. In the $\mathrm{UAE}$, it is estimated that HVAC systems alone account for $40 \%$ of the average energy demand and $60 \%$ of summer peak demand for the country [20]. For this reason, Team UOW put substantial effort into the design of the HVAC system for the Desert Rose house.

After numerous design iterations and refinements, Team UOW decided on using an air-to-water based system for the house. It was decided to use water as it has a much higher specific heat than air, that is, it can transfer a lot more thermal energy using a much smaller volume. This aided in reducing size and energy requirements of the system. The HVAC system is also coupled to thermal energy storage. As peak demand in Dubai occurs during the middle of the day, the organisers of the 2018 solar decathlon require that teams reduce energy consumption between the hours of 12:00pm and 5:00pm. By having a thermal store, the Desert Rose house can shift its peak load, relying on the use of the thermal energy store during this time. Finally, due to the relative humidity in Dubai often reaching over $90 \%$, HVAC systems experience significant latent load. To handle this latent load, the Desert Rose house will make use of a desiccant system. By coupling a desiccant system within the HVAC design, the total rated capacity (in $\mathrm{kW}$ ) of the system can be reduced as a result the desiccant system supplying the latent load and the rest of the system supplying the sensible load.

Finally, the system will be operated using an intelligent control system that considers both the indoor and outdoor environment to optimally coordinate each component of the system. This will ensure the Desert Rose house can maintain the strict indoor environmental conditions of $23^{\circ} \mathrm{C}-25^{\circ} \mathrm{C}, 35-60 \%$ relative humidity and a $\mathrm{C} 02$ concentration less than 800 ppm that are required by the contest organisers.

\section{Team UOW's Lessons Learnt from Two Competitions}

The journey to Datong, China was very much a live and learn experience. Some of the lessons had been passed on by the First Light team from New Zealand but it was still a voyage into the unknown. Vital to both campaigns has been solid encouragement and financial support from the University's top management. The Middle East contest was somewhat easier to sell internally and to the student body because of the SD China success and the tremendous follow on publicity it generated in the city of Wollongong and beyond.

From the SD China experience, we had a much better appreciation of the time required to get things set up and to recruit the right student team. The timelines for the SD Middle East (SDME) were also more favorable than the SD China schedule. With the SDME the project lasts a full two academic years plus 3 months. For SD China, there was just 1.5 academic years. This extra time meant that more of the design and research could be done within a standard academic framework. The students had a little more time to learn about their tasks. This, in turn, has increased the learning opportunities for a wider group of students.

\subsection{Educational Value}

One of the main features of Solar Decathlon competitions is the multi-disciplinary nature of the project. The ten contests for SDME2018 listed in Table 2 have a good mix between engineering and creativity. The Communications contest, for example requires a full and professional communications, marketing and PR strategy covering all forms of media. The 2018 contest re-introduced the separate contest for Innovation which has helped us focus on including as much of our cutting edge research into the DRH. In addition, Team UOW's decision to attempt to solve one of society's growing needs, the accommodation of the growing population of people living with dementia, has provided a platform for bringing a whole new range of students into the project. Team UOW now has 5 main sub-teams: 
Table 3: Team UOW sub-teams for SDME2018.

\begin{tabular}{|l|l|}
\hline Sub Team & Faculties and Schools involves \\
\hline Architecture, Design and Construction & SBRC, Civil Engineering, Creative Arts, TAFE Construction \\
\hline Building Services & Electrical, Comp Sci, Mechanical \\
\hline Communications & Marketing, PR, Creative Arts, Graphics Design, Printing \\
\hline Operations and Logistics & Business, Logistics, Management \\
\hline Livability and Wellbeing & Social Science, HR, Nursing, TAFE Carers, Hospitality \\
\hline
\end{tabular}

In addition, our Innovations coordinator operates across all teams and is our interface with the university's incubator hub, iAccelerate.

One difficulty Team UOW had in China and again in Dubai is the university's lack of a school of architecture. To alleviate this, we have teamed up with practicing architects in the city who mentor our students and we harness the skills of the research architects at the Sustainable Buildings Research Centre, UOW. This approach worked for SD China where our non-architect students still took the gold medal in the Architecture contest!

During the SD China 2013 campaign, over 30 students completed theses and for-credit projects related to the Illawarra Flame House with 10 students completing internships with the team. Two students completed Masters theses and three stayed on to complete their PhD's. A total of 65 students and staff received professional skills training for such things as Site Safety (White Card) training, A number of Chinese exchange students also stayed on to complete PhDs at UOW. Three Team UOW alumni went on to set up their own businesses (two in sustainable construction and one in graphic design). All of the remainder were successfully employed after graduation or went on to higher degree research.

Having had the SD China experience, and a few months before the start of the next academic year, we have had more opportunity to integrate the SDME2018 campaign with the curriculum. In particular, we have been able, this time, to align a number of the required activities with the teaching schedule at the TAFE college. Printers have used Desert Rose for their assignments, painters have been integrated with the decorating and interior design, carers have had input to the dementia enabling design features.

\subsection{Curriculum Integration and Development}

Learnings from SD China pointed us to the need to increase the amount of BIM being taught in the curriculum. During the SD China campaign, we had severe bottlenecks in producing 3D BIM models of the IFH. After the competition, the School of Civil Mining and Environmental Engineering introduced BIM in two subjects while the School of Mechanical Materials and Mechatronics introduced subjects on energy efficiency and HVAC. These subjects helped when we began work on the design of Desert rose House.

Graphic design students in the faculty of Law Humanities and Arts undertook design assignments and major works related to Desert Rose, including developing the logo, branding and artwork for all of the team's documents and stationery.

\subsection{Team Development}

The Solar Decathlon is a large project which takes place over a protracted length of time. This poses challenges with the transient nature of many students. Students nearing the completion of their studies are best positioned to be productive members. This leads to problems with continuity and stability of the team when these student graduate in the middle of the decathlon campaign. It is important to establish a core team of students at post graduate level who can remain with the project through it all and beyond. Team UOW is fortunate to have a dynamic team from the outset and fortunate to have a supportive administration.

The university established $7 \mathrm{PhD}$ scholarships across the disciplines to support Desert Rose. Five of these were filled with high quality domestic and international applicants. Two were difficult to fill at $\mathrm{PhD}$ level and shorter term contracts were established at post doc level in HVAC and Social Science. There are still gaps in the undergraduate training relating to dementia research and HVAC capabilities.

Despite the previous knowledge from SD China, it still proved difficult to build a core team of students covering all the aspects of the contests. It took longer than expected to assemble the skills required. We also found that new entrants of high caliber emerged at unexpected times requiring us to be agile to incorporate them effectively. 
What is evident, as the team grows toward the final showdown in Dubai is that many students have grown from passive player to leaders and have embraced the challenges to display qualities that are not always rewarded by grades. The Solar Decathlon has helped identify many of our future leaders.

\section{The Future of Solar Decathlon}

The contest devised by Dr. Richard King of the US DoE almost 2 decades ago has demonstrated impact amongst academia and industry and shaken the apple cart of conventional engineering and architectural education. Typically, the innovations promoted through the Solar Decathlons are 5 years ahead of market and 10 years ahead of design code endorsement. The Solar Decathlon continues to push the envelope across the globe.

The US DoE has announced new competitions in South America, North Africa and Europe. The second SD China takes place in 2018 to cement Asia's solar revolution. Each contest helps to promote the cause of renewable and sustainable energy while also promoting homes that are comfortable and affordable.

We look forward to the outcomes from Solar Decathlon Middle East 2018 and hope for more adventure in Solar Decathlon Europe 2019 - in Szentendre, Hungary and solar Decathlon Africa 2019 in Morocco. It is pleasing to see that DEWA is confident in 2018 to announce the 2020 Middle East contest to coincide with the 2020 World Expo. The centre of gravity in sustainable and solar powered living is shifting.

\section{Conclusion}

A Solar Decathlon is a significant undertaking for any university or group of universities. The total cost of the endeavor is huge but the rewards are also great. It is worth examining the motivation of each university that has entered you will see that the value, in terms of delivering high quality educational experiences and developing high leadership skills in students is unparalleled. The quality of the learning experience that the Solar Decathlon creates is not matched by any other pedagogical initiative in engineering or architecture education. This is the best.

\section{References}

[1] S. Vega Sánchez, and E. Rodriguez Ubiñas, "Science behind and beyond the solar decathlon Europe 2012 competition," Energy and Buildings, vol. 83, p. 1-2, 2014.

[2] US_DOE. International Competitions. Solar Decathlon, 2018 [cited 2018 February]. [Online]. Available: https://www.solardecathlon.gov/international.html

[3] US_DOE. About Solar Decathlon, 2018 [cited 2018 February]. [Online]. Available: https://www.solardecathlon.gov/about.html

[4] M. H. S. Eastment, R. Nahan, B. Stafford, C. Warner, E. Hancock, R. Howard, "Solar Decathlon 2002: The Event in Review," National Renewable Energy Laboratory (NREL): Washington DC, 2004.

[5] C. L. Warner, and M. R. Wassmer, "Solar Decathlon results and strategies: A closer look," in American Solar Energy Society - Solar 2006: 35th ASES Annual Conf., 31st ASES National Passive Solar Conf., 1st ASES Policy and Marketing Conf., ASME Solar Energy Division Int. Solar Energy Conference, 2006.

[6] UOW, T. Illawarra Flame House Details, 2013. [Online]. Available: http://www.illawarraflame.com.au/house.php

[7] SDME2018, Competition Rules, 2018. [cited 2018 February]; [Online]. Available: https://www.solardecathlonme.com/assets/pdf/rules.pdf

[8] M. Barth, et al, "Developing Key Competencies for Sustainable Development in Higher Education," International Journal of Sustainability in Higher Education, vol. 8, no. 4, pp. 416-430, 2007.

[9] M. Torres-Antonini, "Building the future: The solar decathlon as education for future sustainability leadership," Sustainability, vol. 6, no. 1, pp. 48-56, 2013.

[10] J. R. Kos, and B. M. D. Souza, "Educating home users through a solar house: The Ekó House experience," Energy and Buildings, vol. 83, pp. 181-185, 2014.

[11] T. J. McCarthy, "Australasian students shine on the world stage," in Engineering your future: An Australasian Guide, 3rd ed, D. Dowling, Wiley: Sydney, 2015, p. 129-132. 
[12] P. M. T. J. M. Cooper, M. Jones, "The Team UOW Solar Decathlon House: Building Community and Industry Capability and Motivation for Net-Zero Energy Solar Homes," in Asia Pacific Solar research Conference, M.a.P. Watt, R., Editor. 2014, Australian PV Institute.

[13] M. Fiorentini, P. Cooper, Z. Ma, "Development and optimization of an innovative HVAC system with integrated PVT and PCM thermal storage for a net-zero energy retrofitted house," Energy and Buildings, vol. 94, pp. 21-32, 2015.

[14] M. Fiorentini, et al, "Hybrid model predictive control of a residential HVAC system with on-site thermal energy generation and storage," Applied Energy, vol. 187, pp. 465-479, 2017.

[15] SDME2018 (2016). Announcement of SDME2018.[Online]. Available: https://www.solardecathlonme.com

[16] R. B. Fleming. (2017). Using the Built Environment to create comprehensible manageable and meaningful environments for people with dementia [Online]. Available: https://www.dta.com.au/wpcontent/uploads/2017/02/Intro_Resource1-31.1.17.pdf

[17] L. H. Brown, H. Anh La, "Economic cost of dementia in Austrlaia 2016-2056," Institute for Governance and Policy Analysis: Canberra, 2016.

[18] T. Salama, A. Salah, O. Moselhi, "Configuration of Hybrid Modular Construction for Residential Buildings," International Journal of Innovation, Management and Technology, vol. 8, no. 2, pp. 106-112, 2017.

[19] J. Martin. (2016). The fall and fall of rooftop solar prices: four years of data [Online]. Available: http://reneweconomy.com.au/fall-fall-rooftop-solar-prices-four-years-data-31491/

[20] K. Rakhshan, and W.A. Friess, "Effectiveness and viability of residential building energy retrofits in Dubai," Journal of Building Engineering, vol. 13, pp. 116-126, 2017. 